\section{Ethylene Enhanced Heat Damage to Flavedo Tissue of Cured Citrus Fruits}

\section{S. Ben-Yehoshua ${ }^{1}$ B. Shapiro ${ }^{1}$, and I. Shomer ${ }^{2}$ Agricultural Research Organization, The Volcani Center, P. O. Box 6, Bet Dagan, Israel}

Additional index words. pomelo, lemon, ethephon, darkening, oil gland cells
Individual seal-packaging with plastic film has been developed during the past decade as a new technique for postharvest handling of fruits and vegetables (Ben-Yehoshua, 1985). Recently, we showed that curing sealed fruit at relatively high temperatures for 3 days accelerated healing of fruit injuries and reduced fruit decay (Ben-Yehoshua et al., 1986, 1987). Shrink seal-packaging in plastic film is essential for the curing, as it provides a water-saturated atmosphere and protects the fruit from damage caused by the high curing temperatures.,

In our first attempt to use curing in a fruit packinghouse, we encountered an unexpected difficulty that is detailed below and involves a previously unreported effect of ethylene, i.e., enhanced heat damage to flavedo tissue of citrus fruit.

The seal-packaging and curing operations were carried out according to Ben-Yehoshua et al. (1987). Pomelo fruit (Citrus grandis L. Osbeck CV. Goliath) and lemons (Citrus limon Burro f. cv. Eureka) were obtained directly from orchards. Cryovac D-955 film (W.R. Grace, Duncan, S. C.) was used.

In citrus packinghouses, the ethylene degreening chambers are provided with heating facilities. Consequently, we thought that these chambers would be suitable for our curing applications. We placed pomelos at $35 \pm$ $0.5 \mathrm{C}$ in a degreening chamber that was supposed to be free of ethylene, but, as we later discovered, was not. After 3 days, the fruit surface showed dark, superficial staining. The damage occurred primarily around the oil gland cells of the flavedo. As we suspected ethylene impurity to be the cause, we checked the effect of a dip in ethephon, which is one practical way of applying ethylene, and found that the damage could be reproduced by the combined ethephon and curing treatments (Fig. 1).

Received for publication 3 Feb. 1989. Contribution from the Agricultural Research Organization, The Volcani Center, Bet Dagan, Israel. No. 2580 E. 1989 series. This work was supported in part by a grant from the United States-Israel Binational Agricultural Research and Development Fund (BARD). We thank Y. Sharoni, N. Shem-Tov, and A. Enoch-Levy for excellent technical assistance, and A. Golomb and D. Reinhartz for their help in many aspects of this work. The cost of publishing this paper was defrayed in part by the payment of page charges. Under postal regulations, this paper therefore must be hereby marked advertisement solely to indicate this fact.

'Dept. of Fruit and Vegetable Storage. ${ }^{2}$ Dept. of Food Science.
Pomelos and lemons dipped in 2000 and $4000 \mu \mathrm{l}$ ethephon/liter were compared to fruit dipped in $\mathrm{H}_{2} \mathrm{O}$. After dipping, pomelos were cured for $72 \mathrm{hr}$ at the following temperatures: $33 \pm 0.5,36 \pm 0.5$, and $39 \pm 0.5 \mathrm{C}$; lemons were cured only at $42 \pm 0.5 \mathrm{C}$. After curing, the fruit was kept at $17 \pm 0.5 \mathrm{C}$. The damage was seen at $33 \mathrm{C}$ over $\approx 30 \%$ of the fruit surface in the ethephon-dipped fruit; no damage was observed in the unclipped fruit. At 36C, again only the ethephon-treated fruit was damaged, with stains over $40 \%$ of the fruit surface. At 39C, the ethephon-treated fruit was completely covered with stains, but the untreated pomelo fruit remained normal.

Lemons dipped in ethephon and cured at $42 \mathrm{C}$ were completely brown (Fig. 2). Sealed lemons were much less dark than nonsealed fruit. The lemons that were not treated by ethephon showed only slight browning (Fig. 2).

Morphological observation showed that the oil gland cells of the stained parts of the fruit were hollow. These hollow gland cells were seen in ethephon-treated fruit at 33C, but not in the untreated fruit, even at 36C. Untreated fruit at 39C had a few hollow gland cells. The gland cells may have become hollow because of ethylene-catalyzed heat destruction of the selective properties of the cellular membrane, which resulted in the leakage of the gland cell's content.

The above observations led us to conclude that curing should be performed under conditions that do not allow ethylene to accumulate. Furthermore, any application of this new technique should be carefully tested before large-scale implementation.
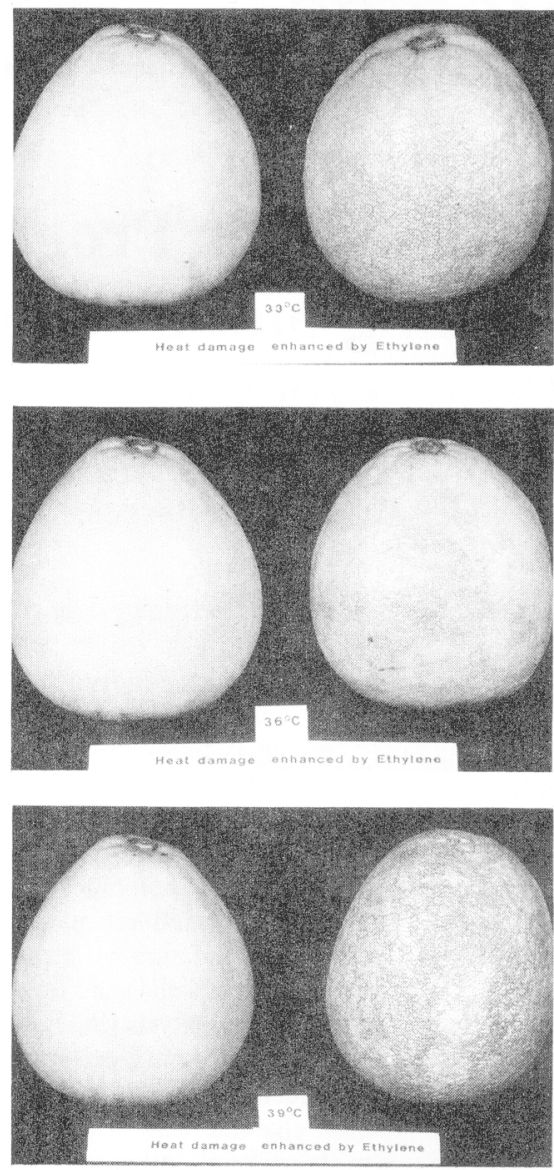

Fig. 1. Ethylene-enhanced heat damage to cured pomelo fruit. The specified temperatures were applied to sealed fruit for $72 \mathrm{hr}$ in the curing chamber.

Literature Cited

Ben-Yehoshua, S. 1985. Individual seal-packaging of fruit in plastic film, a new postharvest technique. HortScience 20:32-37.

Ben-Yehoshua, S., B. Shapiro, I. Gero, and E. Barak. 1986. Seal packaging and curing of lemon and pomelo fruit in order to reduce decay and extend life of fruit. Hassadeh 66:1150-1156.

Ben-Yehoshua, S., B. Shapiro, and R. Moran. 1987. Individual seal-packaging enables the use of curing at high temperatures to reduce decay and heal injury of citrus fruits. HortScience $22: 777-783$.
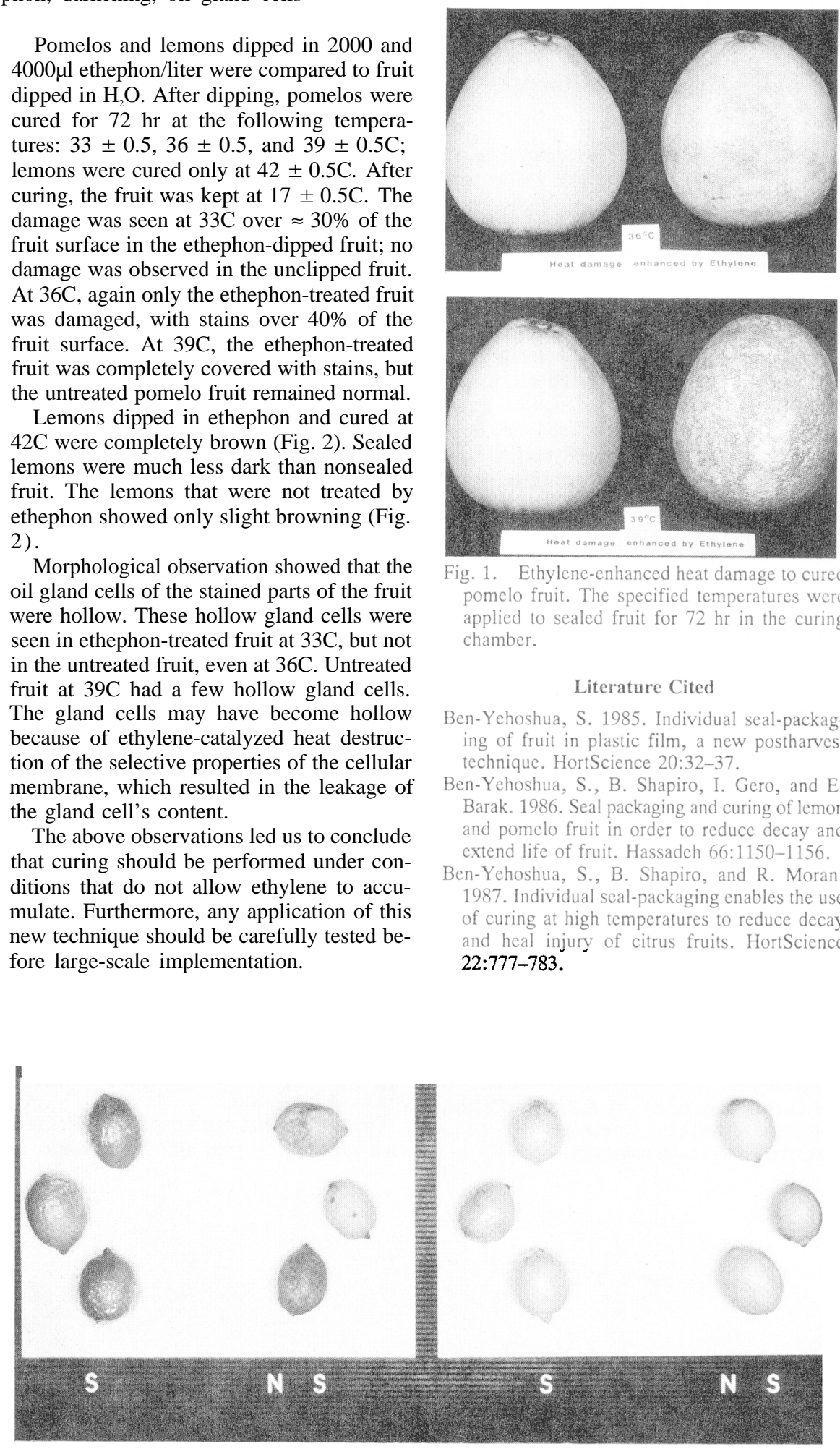

Fig. 2. Ethylene-enhanced heat damage to lemon fruit. The fruit was cured fur 3 days at $42 \mathrm{C}$ either sealed (S) or not sealed (NS). Ethephon-treated fruit (left). Control fruit (right). 